
Saltstone Vault

by

\author{
A. D. Yu \\ Westinghouse Savannah River Company \\ Savannah River Site \\ Aiken, South Carolina 29808 \\ P. S. Lam
}

R. H. Hsu

A document prepared for INTERNATIONAL CONFERENCE ON COMPUTATIONAL ENGINEERING SCIENCES at Mauna Lani from 07/30/95 - 08/03/95.

DOE Contract No. DE-AC09-89SR18035

This paper was prepared in connection with work done under the above contract number with the U.S.

Department of Energy. By acceptance of this paper, the publisher and/or recipient acknowledges the U. S.

Government's right to retain a nonexclusive, royalty-free license in and to any copyright covering this paper, along with the right to reproduce and to authorize others to reproduce all or part of the copyrighted paper. 


\section{DISCLAIMER}

This report was prepared as an account of work sponsored by an agency of the United States Government. Neither the United States Government nor any agency thereof, nor any of their employees, makes any warranty, express or implied, or assumes any legal liability or responsibility for the accuracy, completeness, or usefulness of any information, apparatus, product, or process disclosed, or represents that its use would not infringe privately owned rights. Reference herein to any specific commercial product, process, or service by trade name, trademark, manufacturer, or otherwise does not necessarily constitute or imply its endorsement, recommendation, or favoring by the United States Government or any agency thereof. The views and opinions of authors expressed herein do not necessarily state or reflect those of the United States Government or any agency thereof.

This report has been reproduced directly from the best available copy.

Available to DOE and DOE contractors from the Office of Scientific and Technical Information, P.O. Box 62, Oak Ridge, TN 37831; prices available from (615) 576-8401.

Available to the public from the National Technical Information Service, U.S. Department of Commerce; 5285 Port Royal Road, Springfield, VA 22161. 


\section{DISCLAIMER}

Portions of this document may be illegible in electronic image products. Images are produced from the best available original document. 
WSRC-MS-95-0084

\section{EFFECT OF ROOF SLOPE AND THICKNESS ON THE PERFORMANCE OF A SALTSTONE VAULT}

by

A. D. Yu, P-S Lam, and R. H. Hsu

Savannah River Technology Center, Westinghouse Savannah River Company

P.O. Box 616

Aiken, SC 29802

A paper for presentation at the International Conference on Computational Engineering Sciences

Mauna Lani, Big Island of Hawaii, USA

July 30-August 3, 1995

and for publication in the proceedings.

The information contained in this article was developed during the course of work under Contact No. DE-AC09-89SR18035 with the U. S. Department of Energy. By acceptance of this paper, the publisher and recipient acknowledges the U. S. Government's right to retain a non-exclusive, royalty-free license in and to any copyright covering this paper along with the right to reproduce all or part of the copyrighted paper. 


\title{
EFFECT OF ROOF SLOPE AND THICKNESS ON THE PERFORMANCE OF A SALTSTONE VAULT
}

\author{
Andrew D. Yu, Poh-Sang Lam, and Robert H. Hsu \\ Westinghouse Savannah River Company, Aiken, SC, USA
}

\section{INTRODUCTION}

At the Savannah River Site, low-level radioactive decontaminated salt solution is mixed with slag, flyash, and cement to form a grout-like material called "Saltstone." The Saltstone is poured into concrete vaults constructed at the Saltstone Disposal Facility (SDF) [1]. The SDF is designed for the release of contaminants in a slow, controlled manner over thousands of years. The impact of SDF on groundwater has been studied in a radiological performance assessment (PA) $[2,3]$. The PA addresses the performance requirements or objectives mandated by DOE Order 5820.2A [4]. One of the performance objectives is to show that the impacted groundwater will be in compliance with the Safe Drinking Water Act (SDWA) [5].

Groundwater models were used to predict the fluid flow and contaminant transport at SDF [6]. Nitrate was a key contaminant. The models predicted a spatial contaminant concentration distribution in groundwater as a function of time. The SDWA mandates that the predicted concentration for any contaminant be lower than its maximum concentration limit (MCL) at a compliance point, over a performance period of 10,000 years. The MCL for nitrate is $45 \mathrm{mg} / \mathrm{L}$. A compliance point is $100 \mathrm{~m}$ or farther from the disposal facility.

This study focuses on the roof configuration of Saltstone vault, with special interests in cost-effectiveness. We conducted a sensitivity study to evaluate the effect of roof slope and thickness on the performance of a Saltstone vault. Four roof configurations were simulated: 1) flat roof with a uniform thickness of $2 \mathrm{ft}, 2$ ) flat roof with a uniform thickness of $4 \mathrm{ft}, 3$ ) $2 \%$ slope roof with an average thickness of $2 \mathrm{ft}$;) $2 \%$ slope roof with an average thickness of $4 \mathrm{ft}$. Substituting the $4-\mathrm{ft}$ roof with a 2 - $\mathrm{ft}$ roof will reduce the project cost by approximately $\$ 2,000,000$ per vault.

The tool used for the simulation was ECLIPSE, a finite-difference petroleum reservoir engineering code with an environmental tracer option. Nitrate was used as the "tracer" contaminant. In this study, ECLIPSE solves the two-phase (air-water) two-dimensional (x$z$ vertical slice) flow and transport problem up to 10,000 years. The properties of all materials are assumed to remain unchanged. This paper describes a modeling study used to evaluate roof design options for the Saltstone vault. 


\section{The Saltstone Disposal Facility}

The SDF will consist of 15 concrete vaults. The first vault, completed in 1990, is $100-\mathrm{ft}$ wide by $600-\mathrm{ft}$ long by $25-\mathrm{ft}$ high $(30.5 \mathrm{~m} \times 183 \mathrm{~m} \times 7.6 \mathrm{~m})$. It contains six $100 \mathrm{ft} \times 100 \mathrm{ft}$ $(30.5 \mathrm{~m} \times 30.5 \mathrm{~m})$ cells. Thickness of the Saltstone vault bottom slab is $2 \mathrm{ft}(0.61 \mathrm{~m})$. The side walls are $1.5 \mathrm{ft}(0.46 \mathrm{~m})$ thick. The vaults will be filled with a monolith of Saltstone up to a height of $24 \mathrm{ft}(7.3 \mathrm{~m})$. A layer of clean concrete will then be poured above the Saltstone as the roof. The original design for the Saltstone roof has a slope of $2 \%$ and an average thickness of $4 \mathrm{ft}(1.2 \mathrm{~m})$. This corresponds to heights of $4.5 \mathrm{ft}(1.8 \mathrm{~m})$ at the center ridge and $3.5 \mathrm{ft}(1.4 \mathrm{~m})$ at the edges. Prior to closure, the bottom of the vaults is at the ground level which is at least $20 \mathrm{ft}(6.1 \mathrm{~m})$ above the historical high water table.

After all the vaults are filled, the SDF will undergo closure. The closure plan has not been completed. The current closure concept includes the placement, from the top of the vault to the ground surface, of two feet of clay, one foot of gravel, two feet of backfill soil, two feet of clay, one foot of gravel, and two feet of top soil. The purpose of the closure is to reduce rain water infiltration, to prevent an inadvertent intruder from exposure to the waste, and to minimize the probability of waste exposure by erosion.

\section{MODELING METHODOLOGY}

A two-dimensional vertical cross-section of a Saltstone vault was modeled. The closure cap was included in the simulation domain. The bottom of the simulation domain was a "numerical aquifer." The elevation at this level was arbitrarily chosen to be zero. The Saltstone and the concrete vault were assumed to be initially saturated with water. The initial nitrate concentration in the Saltstone pore fluid was $0.16 \mathrm{~g} / \mathrm{cm}^{3}$. Nitrate in the vault and the backfill soil was assumed to be negligible.

The boundary conditions used for the simulation were: 1) constant water influx of 40 $\mathrm{cm} / \mathrm{yr}$ at the top of the domain; 2) a 1-ft air layer at the top; 3) a 1-ft numerical aquifer layer at the bottom; 4) a vertical barrier and gravel drain to one side of the domain; and, 5) zero convective and diffusive fluxes at the vertical boundaries due to symmetry. The $40 \mathrm{~cm} / \mathrm{yr}$ water influx was the average infiltration rate at SRS. The air layer was maintained at 1.0 atmospheric pressure. The numerical aquifer was connected to a relatively large aquifer to maintain a stable water table condition. The vertical barrier and gravel drain were an approximation that allowed the removal of run-off water without modeling the whole SDF.

The ECLIPSE code [7] was used for the simulation. ECLIPSE is a finite-difference petroleum reservoir engineering code with an "environmental tracer" option. We used ECLIPSE for this study because of its robust equation solver and the "corner point geometry" option. This option allows us to use non-rectangular grids for the sloped roof 
and closure. The conceptual model and simulation grid for a $2 \%$ slope, $4 \mathrm{ft}$-roof is depicted in Figure 1.

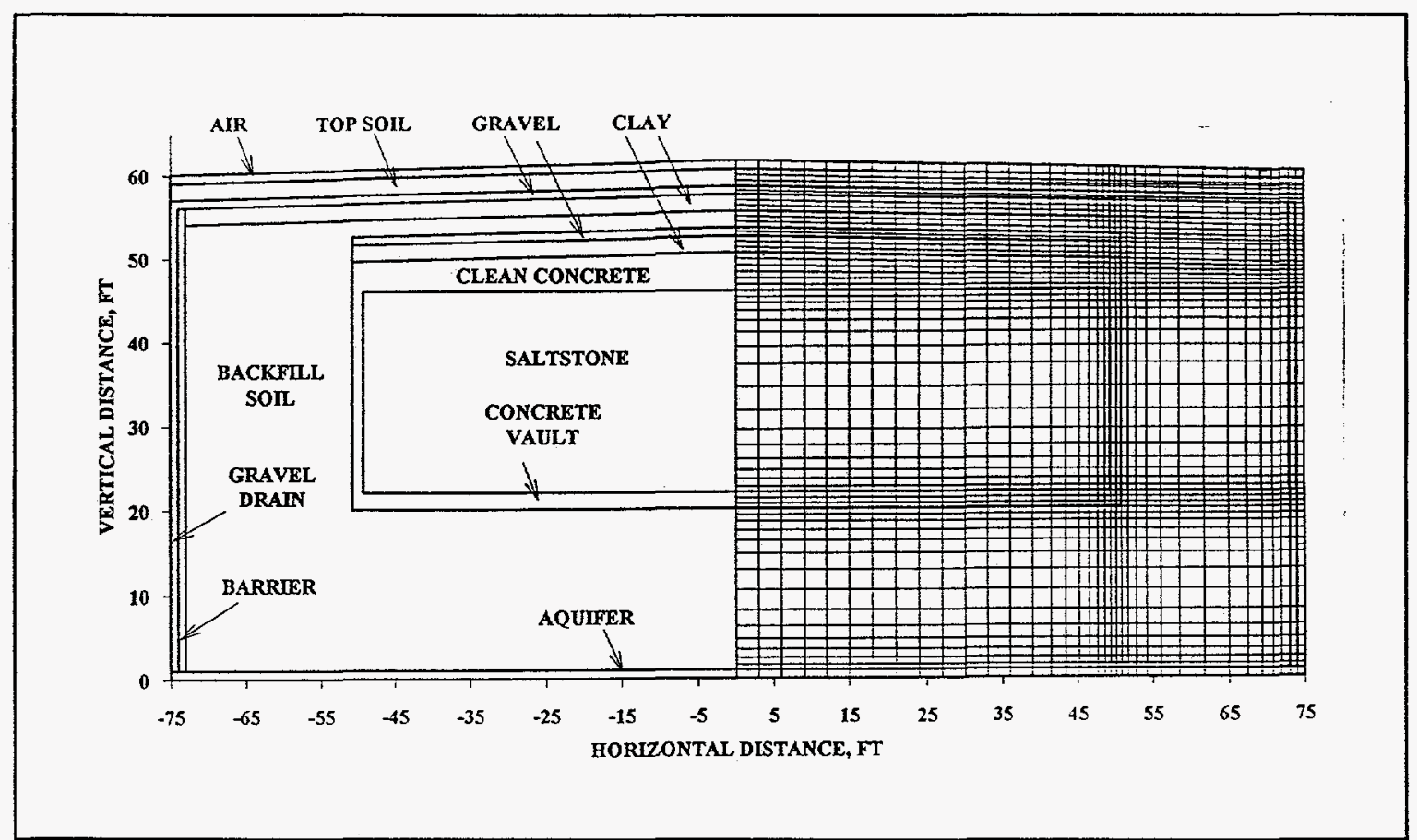

Fig. 1 Conceptual Model and Simulation Grid, 2\% Slope, $4 \mathrm{ft}$ Roof.

Only half a vault was used for the simulation model to take advantage of symmetry. Nitrate was chosen as the contaminant because it does not absorb or decay and is most abundant in the decontaminated salt solution. Nitrate was initially in the Saltstone and then migrated to the surroundings by convection and diffusion. In this study, ECLIPSE solves the two-phase (air-water) two-dimensional ( $\mathrm{x}-\mathrm{z}$ vertical slice) flow and transport problem up to 10,000 years. The properties of all materials are assumed to remain unchanged.

\section{TRANSPORT MECHANISM}

The dominant mechanisms for nitrate release from the Saltstone are convection and diffusion. Convection results from a very small amount of perched water flowing through the vault and acts to leach out nitrate. Diffusion results from the concentration gradient between the Saltstone and the model boundaries. Simultaneous transient flow and transport were simulated. 
The relative importance between convection and diffusion is governed by the flow and transport properties of the porous media. It was assumed that the properties of the materials remain unchanged during the entire modeled period. For this study, the hydraulic conductivities of and the diffusivities for nitrate in Saltstone, concrete, backfill soil and clay are as follows:

\begin{tabular}{ccc}
\hline Material & $\begin{array}{c}\text { Conductivity } \\
(\mathrm{cm} / \mathrm{sec})\end{array}$ & $\begin{array}{c}\text { Diffusivity } \\
(\mathrm{cm} / \mathrm{sec})\end{array}$ \\
\hline Saltstone & $1.0 \times 10^{-10}$ & $1.0 \times 10^{-8}$ \\
Concrete & $1.0 \times 10^{-10}$ & $1.0 \times 10^{-8}$ \\
Backfill Soil & $1.0 \times 10^{-4}$ & $5.0 \times 10^{-6}$ \\
Clay & $1.0 \times 10^{-7}$ & $1.5 \times 10^{-6}$ \\
\hline
\end{tabular}

The conductivities of Saltstone and concrete used are somewhat higher than laboratory measurements [8] for conservatism. The characteristics (capillary pressure and relative permeability) of the materials could also affect the convective transport. Additional sensitivity studies showed they were not as important as the conductivities and diffusivities. Other mechanisms that may affect contaminant transport are absorption, decay, chemical reactions, and solubility limits. They were believed to be unimportant for nitrate because nitrate is non-absorbing, non-decaying, non-reactive and highly soluble.

\section{RESULTS AND DISCUSSIONS}

The predicted rate of nitrate released to the water table $(\mathrm{g} / \mathrm{yr})$ was divided by the total initial nitrate inventory in the modeling domain to obtain the fractional release rate $\left(\mathrm{yr}^{-1}\right)$. The fractional releases for the four scenarios are shown in Figure 2. In this figure, the $0 \%$ slope, $2 \mathrm{ft}$ roof case (Case 1) showed highest nitrate fractional release rates. The curve peaked to $9.0 \times 10^{-6}$ per year at about 3,800 years after waste disposal. In the $2 \%$ slope, 2 $\mathrm{ft}$ roof case, predicted peak nitrate release was $4.4 \times 10^{-6}$ per year at about 8,000 years. The performance was improved by $50 \%$ at essentially no additional cost to Case 1 . Increasing the roof thickness to $4 \mathrm{ft}$ will also improve the performance. However, we believe this action will not justify its additional cost.

The release rate histories were used as source terms for the saturated-zone model to calculate the nitrate concentrations in the groundwater. Predicted groundwater peak concentration was proportional to the peak fractional release rate. It happened shortly after the peak fractional release because the groundwater velocity in the shallow aquifer was 
approximately $300 \mathrm{~m} / \mathrm{yr}$ and the compliance point was only $100 \mathrm{~m}$ from the facility boundary. The regulatory maximum concentration limit (MCL) for nitrate is $45 \mathrm{mg} / \mathrm{L}$. Predicted nitrate peak fractional releases and peak groundwater concentrations $\left(\mathrm{C}_{\max }\right)$ at the compliance points are summarized in Table 1 .

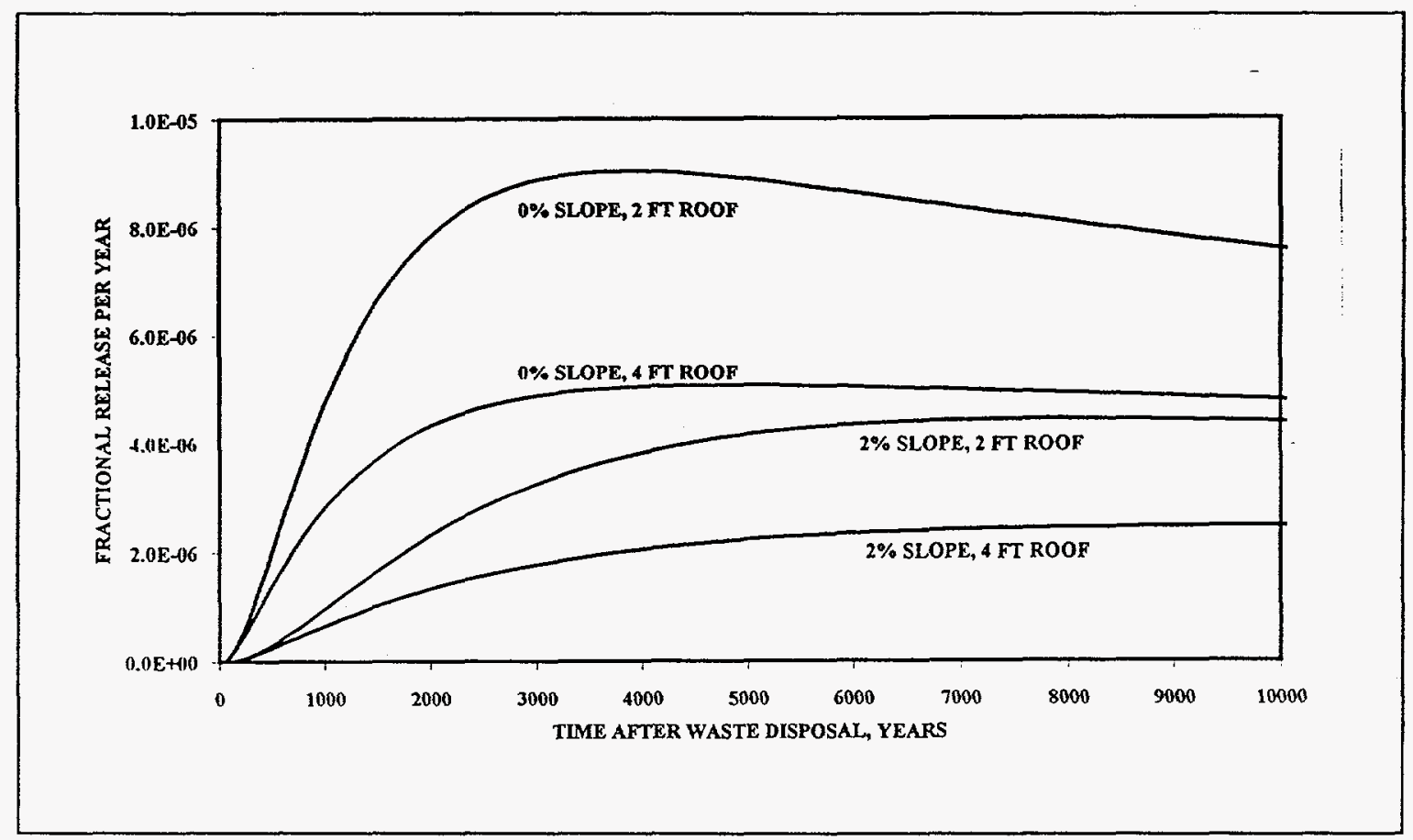

Fig. 2. Predicted Fractional Release Rates.

\begin{tabular}{|c|c|c|c|}
\hline \multirow{2}{*}{ Cases } & \multicolumn{2}{|c|}{$\begin{array}{c}\text { Maximum Fractional Release } \\
\text { (per year) }\end{array}$} & $\begin{array}{c}\mathrm{C}_{\max } \\
(\mathrm{mg} / \mathrm{L})\end{array}$ \\
\hline & Value & At Year & Value \\
\hline $0 \%$ slope, $2 \mathrm{ft}$ & $9.0 \times 10^{-6}$ & 3,800 & 2.1 \\
\hline $0 \%$ slope, $4 \mathrm{ft}$ & $5.1 \times 10^{-6}$ & 4,700 & 1.2 \\
\hline $2 \%$ slope, $2 \mathrm{ft}$ & $4.4 \times 10^{-6}$ & 8,000 & 1.0 \\
\hline $2 \%$ slope, $4 \mathrm{ft}$ & $2.5 \times 10^{-6}$ & 10,000 & 0.6 \\
\hline \multicolumn{2}{|c|}{ Maximum Concentration Limit } & 45. \\
\hline
\end{tabular}

Table 1. Predicted Peak Nitrate Fractional Releases and Groundwater Concentrations. 
Based on the modeling results, we found: 1) Increasing the roof thickness from $2 \mathrm{ft}$ to 4 $\mathrm{ft}$ only improves the SDF performance by $40 \%$. 2) Changing the slope of the roof from $0 \%$ to $2 \%$ improves the SDF performance by $50 \%$. The time of the peak is also doubled. 3) A reduction of roof thickness from $4 \mathrm{ft}$ (original design) to $2 \mathrm{ft}$ can result in project cost saving of approximately $\$ 2,000,000$ per vault. 4) Predicted peak nitrate concentrations in the groundwater for all four cases are well below the $45 \mathrm{mg} / \mathrm{L} \mathrm{MCL}$. This probably results from the assumptions of intact Saltstone and vault.

\section{ACKNOWLEDGMENT}

This work was sponsored by the U.S. Department of Energy Office of Environmental Restoration and Waste Management under DOE Savannah River Field Office Contract No. DE-AC09-89SR18035.

\section{REFERENCES}

[1] C. A. Langton, S. B. Oblath, D. W. Pepper, and E. L. Wilhite. "Waste Salt Disposal at the Savannah River Plant." Chem. Eng. Comm., Vol. 66: 189-199. 1988.

[2] Westinghouse Savannah River Company. "Radiological Performance Assessment for the Saltstone Disposal Facility." prepared by Martin Marietta Energy Systems, Inc., EG\&G Idaho, Inc., and Westinghouse Savannah River Company. 1992.

[3] J. R. Cook and J. R. Fowler. "Summary of Information Developed for the Saltstone RPA." SRT-WED-93-203. July 8, 1993.

[4] US Department of Energy. "Radioactive Waste Management." DOE Order 5820.2A September 26, 1988.

[5] US Department of Energy. "Safe Drinking Water Act." Environmental Guidance Program Reference Book prepared by the Oak Ridge National Laboratory, Oak Ridge, TN 37831. ORNL/M-1127. June 1990

[6] A. D. Yu and S. O. Magnuson. "Simulation of Contaminant Release from a Saltstone Vault," Simulators X, Proceedings of the 1993 International Simulators Conference, Vol. 25, No. 4, pp. 505-511. 1993

[7] Intera. "ECLIPSE 100 Reference Manual." by Intera Information Technologies Limited, Oxfordshire, England. 1993.

[8] A. D. Yu, C. A. Langton, and M. G. Serrato. "Physical Property Measurement Program." WSRC-RP-93-849, Westinghouse Savannah River Company, Aiken, SC. June 30, 1993. 